\title{
Can US Fiscal Stimulus Negatively Affect US Balance of Trade?
}

\author{
Deergha Raj Adhikari \\ University of Louisiana at Lafayette \\ Spuma Rao
University of Louisiana at Lafayette \\ Denis Boudreaux \\ University of Louisiana at Lafayette
}

In an attempt to take the U.S. economy out of recession or to stimulate a sluggish economy, US presidents, democrats and republicans alike, have used an expansionary fiscal policy. While an expansionary fiscal policy raises the GDP, it also raises a nation's import due to increased income brought about by the expansionary fiscal policy. If the increase in a nation's import exceeds that in export, it negatively impacts the nation's balance of trade. So, our study examines the impact of US government stimulus spending on the nation's balance of trade. We use a general equilibrium framework and apply the VECM model on US data from 1980 to 2020. Our study finds that, while the long-run impact of US fiscal stimulus spending on US balance of trade is positive and significant, the short-run impact is negative. We also found that any short term fluctuation in US balance of trade is adjusted to its long-run equilibrium level.

Keywords: fiscal stimulus spending, balance of trade, stationarity, cointegration, VECM, short-run impact, long-run impact

\section{INTRODUCTION}

In an attempt to take the U.S. economy out of the Great Depression that started in 1929, President Franklin D. Roosevelt used expansionary policy by initiating several public works projects. Although this policy worked fine in overcoming the economy from the Great Depression, an effort later by the president to balance the economy put it back into the depression. This prompted him to use an expansionary fiscal policy one more time. Later in that century, President John F. Kennedy used expansionary fiscal policy to stimulate the economy out of the 1960 recession.

Right in the beginning of the $21^{\text {st }}$ century the US economy again underwent a recession following the so-called tech bubble bust. This prompted the Bush administration to use an expansionary fiscal policy through the Economic Growth and Tax Relief Reconciliation Act. The act authorized the Bush administration to mail out stimulus payments to US households and to lower income tax slabs. Later the shaken confidence of US consumers and investors in the nation's defense caused by the terrorist attacks of September 11, 2001 sent the U.S. economy back into a recession. This event laid the president 
launch a war on terror and cut business taxes in 2003 through the Jobs and Growth Tax Relief Reconciliation Act.

Similarly, the American Recovery and Reinvestment Act passed by the US congress enabled the Obama administration to use an expansionary fiscal policy in 2009 to recover the economy from the recession caused by a demand shock mainly due to the housing bubble bust combined with a supply shock due to surges in oil prices. The Act enabled the government to cut taxes, extend unemployment benefits, and fund public works projects. The law cost $\$ 787$ billion in tax cuts and government spending.

Recently, the Trump administration used an expansionary fiscal policy though the so-called the Tax Cuts and Jobs Act, which allowed the government to increase discretionary spending-especially for defense.

So, although guided by different economic principles and practices, democratic and republican presidents alike have time and again used an expansionary fiscal policy. While republican presidents in general insist on cutting business taxes and lowering income tax rates, democratic presidents, on the other hand, insist on supporting low-income people and increasing public works spending.

Cutting business taxes spurs investment, which in turn creates employment, generates income and stimulates the economy. This is the argument generally forwarded by those on republican side. The democrats, on the other hand, offer the argument that financial support to low-income people and spending on public works projects create demand in the economy raising expected profit for the businesses, thereby raising investment, employment, and income and ultimately stimulating the economy. The chart below exhibits that all recent 3 presidents (republicans and democrat): President Bush (2001-2008), President Obama (2009-2016), and President Trump (2017-2020) have used an expansionary fiscal policy during their tenure causing huge budget deficits ultimately resulting in pilling up of national debts. 
TABLE 1

US BUDGET DEFICIT OF SURPLUS (TRILLIONS OF DOLLARS)

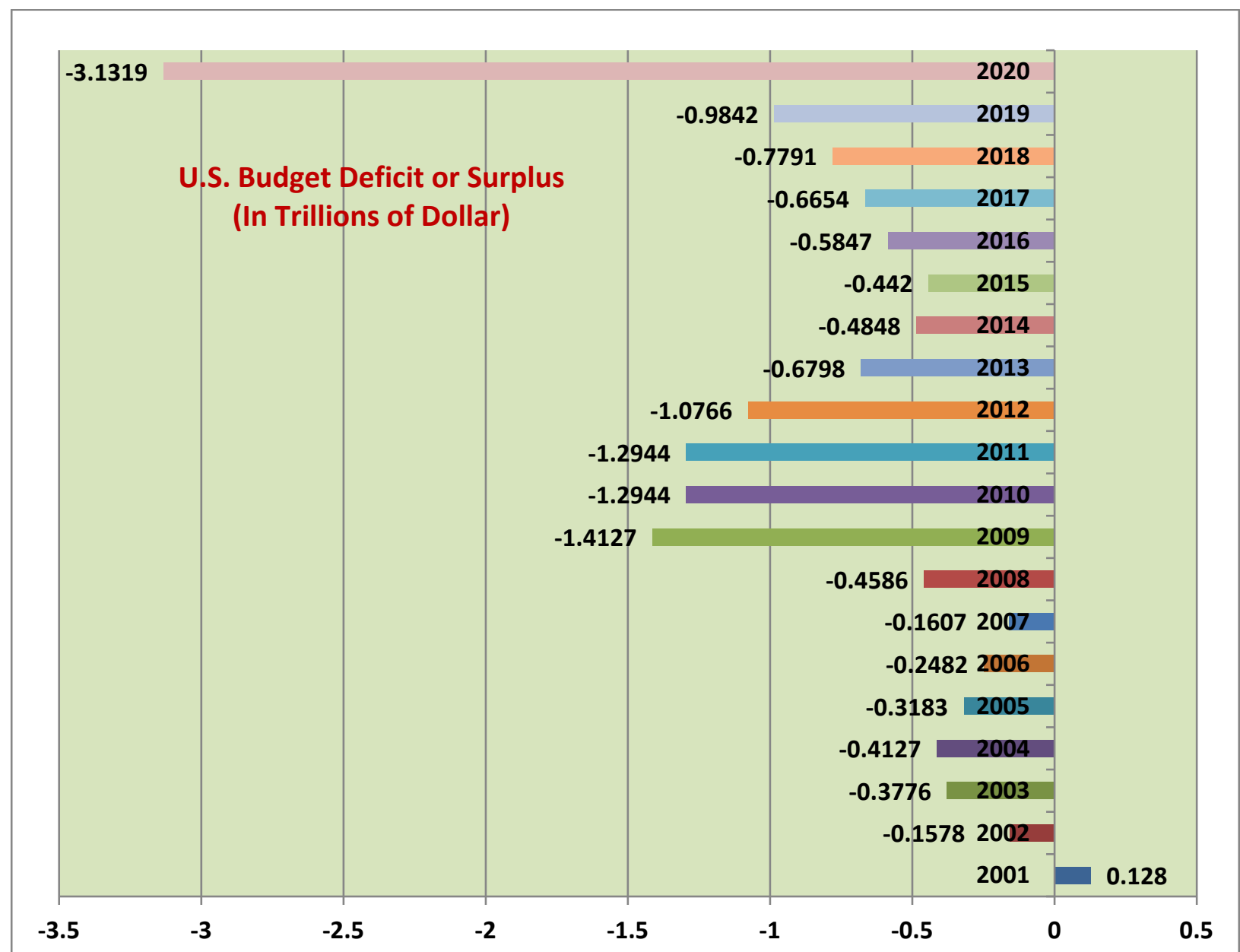

Source: Economic Report of the President, 2021: https://www.govinfo.gov/content/pkg/ERP2021/pdf/ERP-2021.pdf

While an expansionary fiscal policy raises a nation's GDP, it also raises the nation's aggregate demand. Since a portion of a nation's increased demand is met by the supply of goods and services produced in foreign countries, increase in nation's demand is followed by increase in imports. Similarly, a portion of the nation's output is purchased by foreigners, an increased GDP tends to raise the nation's export. If the increase in a nation's export exceeds the increase in the nation's imports, it results in an increase in the nation's net export, in other words, an improvement in balance of trade. The opposite happens, if the increase in the nation's export falls short of the increase in the nation's import. So, it is interesting to examine the impact of US fiscal stimulus on its balance of trade. Our study examines several previous studies conducted on this issue. Cova et al. (2011) in their book on the macroeconomic impact of China's 2009-2010 fiscal stimulus package that simulates a dynamic general equilibrium multi-country model of the world economy, show that the effects on China's economic activity are stronger under a US dollar peg because of the imported loose monetary policy stance from the United States. They also show that the higher Chinese aggregate demand stimulates higher (gross and net) imports from other regions, in particular from Japan and the rest of the world, and only to a lesser extent, from the United States and the euro area.

Corsetti (2009), in his paper, focuses on the case of fiscal stimulus, investigating cross-border spillovers from an increase in exhaustive government spending on the basis of a two-country business cycle model. Their model allows spillovers to be affected by a range of features, including trade elasticity, the size and 
openness of economies, as well as financial imperfections. They conclude that the anticipated spending reversal not only strengthens the domestic stimulus effect but also enhances positive cross-border spillovers through its impact on global long-term interest rates.

A paper by Koh (2017) evaluates the effectiveness of fiscal policy by employing a structural panel vector autoregression model with a shock to fiscal spending identified via theoretical robust sign restrictions. Using an annual data set of 120 countries over the period 1960-2014, they show, contrary to conventional wisdom, fiscal multipliers are not necessarily smaller in countries that are relatively open to trade and capital flows and operating under flexible exchange rate regimes. Also, the relationship between the size of fiscal multipliers and the three dimensions of openness - trade openness, capital mobility, and exchange rate flexibility - hinges on the response of the real exchange rate and the domestic monetary policy pursued.

A study by Aloryito (2016), using data for 41 Sub-Saharan Africa and applying the system Generalised Method of Moments tests the hypothesis of twin deficits. Results from this study indicates that fiscal deficits tend to improve the current account and vice versa, thereby rejecting the twin deficits hypothesis in favor of the twin divergence proposition.

Hur (2010), in his paper, assesses the impact of fiscal stimulus on developing Asia's gross domestic product growth during the crisis. His main finding is that the stimulus has had a significant positive impact, which has helped the region cushion the adverse impact of the collapse in global trade.

Beetsma (2008) investigates the consequences of an increase in public spending for trade balances and budget deficits in the European Union, using a panel vector auto-regression approach. Hi finds that, if they occur in large countries they significantly raise the world real interest rate causing a short-run current account deterioration equal to around $50 \%$ of the fiscal deficit deterioration followed by a long-run current account deterioration equal to almost $75 \%$ for a large economy such as the United States, and almost $100 \%$ for a small open economy.

Adler et al. (2018), in their paper, study the impact of the strong policy response of the United States to the 2008-2009 financial crisis. To them, the effects of the monetary stimulus received significant attention, while those of fiscal policy were largely overlooked, despite the combined deployment of these two policy instruments. This paper studies the trade spillovers of the post-crisis policy mix. They find that overall effects were positive in the immediate aftermath of the crisis, reflecting positive spillovers of fiscal policy that outweighed the negative impact of monetary policy.

Erceg et al. (2005) use a dynamic general equilibrium model of an open economy to assess the quantitative effects of fiscal shocks on the trade balance in the United States. They examine the effects of two alternative fiscal shocks: a rise in government consumption, and a reduction in the labor income tax rate. They find that a fiscal deficit has a relatively small effect on the US trade balance, irrespective of whether the source is a spending increase or tax cut. They find that a rise in the fiscal deficit of 1 percentage point of gross domestic product (GDP) induces the trade balance to deteriorate by 0.2 percentage point of GDP or less. From a policy perspective, their analysis suggests that even reducing the current US fiscal deficit (of 3\% of GDP) to zero would be unlikely to narrow the burgeoning US trade deficit significantly.

Yunanto (2015) analyzes the internal and external equilibrium model of the economy in the short-term preferences fiscal and monetary policy strategy using error correction model of Engle Granger (ECM-EG). The results of this analysis shows that fiscal policy and monetary policy provide significant multiplier effect to stimulate aggregate demand through increased consumption, investment, government consumption, exports and imports.

Nickel and Vansteenkiste (2008), in their paper, analyze the empirical relationship between fiscal policy and the current account. To do so, they estimate a dynamic panel threshold model for 22 industrialized countries in which the relationship between the current account and the government balance is allowed to alter according to the government debt to GDP ratio. The results show that for countries with debt to GDP ratios up to $90 \%$ the relationship between the government balance and the current account is positive, whereas for very high debt countries this relationship turns negative but insignificant. They also find, using the same model for the 11 largest euro area countries, that the relationship between the 
government balance and the current account turns statistically insignificant when the debt to GDP ratio exceeds $80 \%$.

A paper by Choi (2021) sheds new light on the degree of international fiscal-financial spillovers by investigating the effect of domestic fiscal policies on cross-border bank lending. By estimating the dynamic response of U.S. cross-border bank lending towards 45 recipient countries to exogenous domestic fiscal shocks (both measured by spending and revenue) between 1990Q1 and 2012Q4, he finds that expansionary domestic fiscal shocks lead to a statistically significant increase in cross-border bank lending and the size of the effect is comparable to an exogenous decline in the federal funds rate by about $25 \mathrm{bp}$ (50 bp) for spending (revenue) shocks independent of changes in monetary policy or financial conditions measured by the VIX.

Our study contributes to the existing literature of macroeconomics in many significant ways, for example: (1) we use the goods market equilibrium model, (2) our study uses a vector error correction model to analyze the impact of US fiscal stimulus on US balance of trade, (3), we analyze both the short run and the long-run impact of the fiscal stimulus on US balance of trade, and (4) we run several residual testing to ensure the robustness of our model, which, to our knowledge has never been done before at least recently.

\section{THE MODEL}

To analyze the impact of US fiscal stimulus on US balance of trade, we use the general equilibrium model. The goods market is in equilibrium, when the aggregate demand (AD) of the nation equals its aggregate supply (AS), which in fact is the nation's output (GDP). That is, AD = AS = GDP.

Since, a nation's aggregate demand comprises of its household expenditure also called personal consumption expenditure (CON), gross private domestic investment (INV), government consumption expenditure and gross investment (GOV), and net export (NX) also called balance of trade and measured as the nation's exports minus its imports, that is, $\mathrm{AD}=\mathrm{CON}+\mathrm{INV}+\mathrm{GOV}+\mathrm{NX}$.

When the goods market is in equilibrium, $\mathrm{AD}=\mathrm{AD}$. That is,

$\mathrm{GDP}=\mathrm{CON}+\mathrm{INV}+\mathrm{GOV}+\mathrm{NX}$

The above equation can be rewritten as,

$\mathrm{NX}=\mathrm{GDP}-\mathrm{CON}-\mathrm{INV}-\mathrm{GOV}$

It means, any change in GDP, CON, INV, or GOV also affects NX. In other words,

$\mathrm{NX}=\mathrm{f}(\mathrm{GDP}, \mathrm{CON}, \mathrm{INV}, \mathrm{GOV})$

If the mean effect of the variables, GDP, CON, and INV is assumed to be included in the intercept term and their random effect included in the error term, then the function in (3), in its stochastic form, can be expressed as following:

$N X_{t}=a_{0}+a_{1} G O V_{t}+e_{t}$

We apply the above model on US data. We expect the coefficient $\mathrm{a}_{1}$ to be positive, because an increased government spending increases a nation's GDP. Since a portion of a nation's GDP is exported to other countries, an increased government spending is expected to ultimately increase the nation's export and, thereby, the net export. 


\section{DATA}

Data on US net export (NX) defined as exports minus US imports and that on government spending (NX) was collected from the Bureau of Economic Analysis website (https://apps.bea.gov/iTable/iTable.cfm?reqid=19\&step=2\#reqid=19\&step=2\&isuri=1\&1921=survey) and ranges from 1980 to 2020 .

\section{METHODOLOGY AND EMPIRICAL FINDINGS}

Instead of using the model in (4) directly, in our empirical estimation, we use its deflated version where the deflated version uses both the dependent and the independent variables deflated by the GDP. Thus, our empirical model is as following:

$N X T G D P_{t}=a_{0}+a_{1} G O V T G D P_{t}+e_{t}$

where, NXTGDP $=$ NX/GDP and GOVTGDP $=$ GOV/GDP. This specification has one advantage as it lowers the fluctuations in the level variables.

As most time series are nonstationary in levels, we need to find if any long-run relation exist among them. In order for any two variables to be associated by a long-run relationship, both must be integrated of the same order. We, therefore, fist investigate if these two variables are stationary, by conducting the augmented Dickey-Fuller test. The test results are shown below:

TABLE 2

DICKEY-FULLER TEST STATISTICS

\begin{tabular}{llll}
\hline Variable & t-statistic & Critical Value at 5\% & Stationary \\
\hline NXTGDP & -1.73825 & -2.93694 & Non-stationary \\
d(NXTGDP,1) & -4.94025 & -2.93899 & Stationary \\
GOVTGDP & -2.26985 & -2.94115 & Non-stationary \\
d(GOVTGDP,1) & -4.20906 & -2.60907 & Stationary \\
\hline
\end{tabular}

The results show that both variables are integrated of order 1 indicating a possibility of a long-run relationship between them. We, therefore, turn to the Johansen cointegration test to determine if any such relationship exists. Since the test is sensitive to lag length, to conduct the test, we run a vector autoregressive model to determine the appropriate lag length and obtained the above results.

TABLE 3

LAG LENGTH TEST STATISTICS

\begin{tabular}{lllllll}
\hline Lag & $\operatorname{LogL}$ & LR & FPE & AIC & SC & HQ \\
\hline 0 & 222.0399 & NA & $3.20 \mathrm{E}-08$ & -11.5811 & -11.4949 & -11.5504 \\
1 & 296.1165 & 136.4569 & $8.02 \mathrm{E}-10$ & -15.2693 & -15.0107 & -15.1773 \\
2 & 308.6876 & $21.83408^{*}$ & $5.12 \mathrm{E}-10$ & -15.7204 & $-15.28946^{*}$ & -15.5671 \\
3 & 314.3661 & 9.26488 & $4.71 \mathrm{e}-10^{*}$ & $-15.80874^{*}$ & -15.2054 & $-15.59408^{*}$ \\
\hline
\end{tabular}

The results show majority of the criteria selected a lag length of 3. So, using a lag length of 3 we conducted the Johansen cointegration test that produced the following results. 
TABLE 4

JOHANSEN COINTEGRATION TEST RESULTS

\begin{tabular}{lllll}
\hline \multicolumn{5}{c}{ Unrestricted Cointegration Rank Test (Trace) } \\
\hline Hypothesized & Trace & 0.05 & \\
\hline No. of CE(s) & Eigenvalue & Statistic & Critical Value & Prob.** \\
None * & 0.319206 & 17.27763 & 15.49471 & 0.0267 \\
At most 1 & 0.079158 & 3.051274 & 3.841465 & 0.0807 \\
\multicolumn{5}{c}{} \\
\hline \multicolumn{5}{c}{ Unrestricted Cointegration Rank Test (Maximum Eigenvalue) } \\
\hline No. of CE(s) & Eigenvalue & Statistic & Critical Value & Prob.** \\
None * & 0.319206 & 14.22635 & 14.2646 & 0.0507 \\
At most 1 & 0.079158 & 3.051274 & 3.841465 & 0.0807 \\
\hline
\end{tabular}

Both tests indicate that there is at least one cointegrating vector between our two model variables. To determine the long-run and the short-run relationship between the two variables we run a vector error correction model. The estimation results are shown below.

Long-Run Equation:

NXTGDP $_{\mathrm{t}}=-0.28502+1.32699$ GOVTGDP $_{\mathrm{t}}$

(3.64723)

Short-Run Equation:

$$
\begin{array}{rlrl}
\Delta \text { NXTGDP }_{\mathrm{t}}= & -0.1935 \mathrm{ECT}_{\mathrm{t}-1}-0.0042 \Delta \mathrm{NXTGDP}_{\mathrm{t}-1}+0.2663 \Delta \mathrm{NXTGDP}_{\mathrm{t}-2} \\
& (-3.1227) & (-0.0252) & (1.6147) \\
& +0.0993 \Delta \mathrm{NXTGDP}_{\mathrm{t}-3}+0.2648 \Delta \mathrm{GOVTGDP}_{\mathrm{t}-1}-0.7854 \Delta \mathrm{GOVTGDP}_{\mathrm{t}-2} \\
& (0.5985) & (0.9610) & (-2.6958) \\
- & 0.1281 \Delta \mathrm{GOVTGDP}_{\mathrm{t}-3}-0.00067 & \\
& (-0.4603) & (-0.72257)
\end{array}
$$

The figures in parentheses are corresponding t-values. In the long run equation, the coefficient associated with the independent variable, GOVTGDP is statistically significant at 5\% significance level. A positive and significant coefficient associated with this variable indicates that any rise (fall) in government spending to GDP ratio will raise (lower) US net export to GDP ratio in the long run. In the short-run equation, on the other hand, the coefficients associated with the variables, $\triangle G_{\text {GOVTGDP }}-2$ is negative and significant at 5\%. How to interpret this finding? First, in the long run, any increase in US government spending is found to be increasing US net export, which is as expected. This is because an increase in government spending boosts the nation's GDP, a portion of which is exported, thereby, boosting the nation's net export in the long run. In the short run, however, a portion of increased government spending goes to the purchase of foreign products, which raises the nation's imports and, thereby, worsens the nation's net export.

Also, the coefficient associated with the error-correction term, ECT, is negative and significant at 5\% significance level, which implies that any short term fluctuation in US net export will be adjusted toward its long-run value. 


\section{SUMMARY AND CONCLUSION}

In an attempt to take the U.S. economy out of recession or to stimulate a sluggish economy, US presidents, democrats and republicans alike, have used an expansionary fiscal policy.

While an expansionary fiscal policy, on one hand, raises the GDP, it also raises a nation's import due to increased income brought about by the expansionary fiscal policy. On the other hand, since a portion of a nation's GDP is purchased by foreigners, an increased GDP caused by an increased government spending tends to raise the nation's export. If the increase in a nation's export exceeds that in import, it results in an increase in the nation's net export or an improvement in balance of trade. The opposite happens, if the increase in the nation's export falls short of the increase in import. Our study examines the impact of US fiscal stimulus spending or increase in government spending on its balance of trade.

We estimate a vector error correction model (VECM) on data ranging from 1980 to 2020 with NXTGDP (net export to GDP ratio) as dependent variable and GOVTGDP (government spending to GDP ratio) as independent variable. In the long run equation, the coefficient associated with the variable GOVTGDP $_{\mathrm{t}}$ has been found to be positive and significant implying that any increase in government spending improves the nation's balance of trade in the long run. In the short-run equation, on the other hand, the coefficient associated with the variables $\Delta$ GOVTGDP $_{\mathrm{t}-2}$ has been found to be negative and significant, implying that any increase in government spending causes the import to increase immediately before causing a positive impact on GDP and thereby on export, worsening the nation's net export or the balance of trade in the short run. Thus, the findings imply that the national government should be prepared to embrace a shot-term deterioration of the nation's balance of trade following an expansionary fiscal policy.

Also, the coefficient associated with the error-correction term, ECT, is found to be negative and significant, implying that any short-run fluctuation in US balance of trade will be adjusted toward its longrun value.

Our study has certain limitations as it does not investigate all other reasons that can simultaneously affect a nation's balance of trade, which could be a potential area for further studies.

\section{REFERENCES}

Adler, G., \& Buitron, C.S. (2018). Policy Mix and the U.S. Trade Balance. International Finance, 22(2), $138-154$.

Aloryito, G.K., Senadza, B., \& Amponsah, E.N. (2016). Testing the Twin Deficits Hypothesis: Effect of Fiscal Balance on Current Account Balance - A Panel Analysis of Sub-Saharan Africa. Modern Economy, 7(9).

Beetsma, R., Giuliodori, M., \& Klaassen, F. (2008). The Effects of Public Spending Shocks on Trade Balances and Budget Deficits in the European Union. Journal of the European Economic Association, 6(2-3), 414-423.

Choi, S., Fureceri, D., \& Yoon, C. (2021, January 08). International Fiscal-Financial Spillovers: The Effect of Fiscal Shocks on Cross-Border Bank Lending. Open Economies Review.

Corsetti, G., Meier, A., \& Muller, G.J. (2009). Cross-Border Spillovers from Fiscal Stimulus. CPER Discussion Paper No. DP7535.

Cova, P., Pisani, M., \& Rebucci, A. (2011). Macroeconomic Effects of China's Fiscal Stimulus. Asian and China in the Global Economy, pp. 321-349.

Erceg, C.J., Guerrieri, L., \& Gust C. (2005). Expansionary Fiscal Shocks and the US Trade Deficit. International Finance, 8(3), 363-397.

Hur, S-K., Jha, S., Park, D., \& Quising, P. (2010, October). Did Fiscal Stimulus Lift Developing Asia Out of the Global Crisis? Asian Development Bank Economic Working Paper Series, No. 215.

Koh, W.C. (2017). Fiscal Multipliers: New Evidence from a Large Panel of Countries. Oxford Economic Papers, 69(3), 569-590.

Kumbof, M., \& Laxton, D. (2013). Fiscal Deficits and Current Account Deficits. Journal of Economic Dynamics and Control, 37(10), 2062-2082. 
Nickel, C., \& Vansteenkiste, I. (2008, September). Fiscal Policies, the Current Account and Ricardian Equivalence. ECB Working Paper, No. 935.

Yunanto, M., \& Medyawati, H. (2015). Monetary and Fiscal Policy in Internal and External Balance. Interdisciplinary Behavior and Social Science, London. ISBN 978-1-138-02735-0 